\title{
A Historical-Educational Investigation into the Decision To Remove Religious Education from Public Schools in South Africa
}

\author{
Andrew E van Zyl \\ University of South Africa \\ Email:vzylae@unisa.ac.za
}

\section{Doi:10.5901/mjss.2014.v5n20p1613}

\section{Abstract}

This article aims at providing an answer to the question whether the government's removal of religious education from the public schools of South Africa can be justified from a historical-educational perspective. In order to answer this question, a historical-educational investigation, based on the historical-educational method, was undertaken concerning relevant information pertaining to three foci: formal South African education during early colonial days, nineteenth century education at the Cape and the philosophy of Christian National Education. The latter is interrogated in terms of its meaning and aims, its support of the religious-political ideas of Abraham Kuyper (1837-1920) and its ties with the Afrikaner Broederbond ("Afrikaner Brotherhood"). This article concludes that the decision to remove religious education which featured in subjects from public schools was justified.

Keywords: Religion education; religious education; Christian National Education; Abraham Kuyper; Afrikaner Broederbond

\section{Introduction}

In this section this research is contextualized by means of relevant South African legislation which serves as theoretical framework for interpreting historical data. This is followed by the research question and the methodology which underpins this research.

The liberation of South Africa had far reaching educational implications rooted in its supreme law, the Constitution of the Republic of South Africa (Act 108 of 1996), which is considered to be one of the most advanced constitutions in the world in terms of its clear promulgation of democracy. In its Chapter 2 (Bill of Rights) it is stated that

\begin{abstract}
[t]he state may not unfairly discriminate against anyone directly or indirectly on one or more grounds including race, gender, sex, pregnancy, marital status, ethnic or social origin, colour, sexual orientation, age, disability, conscience, belief, culture, language and birth (Republic of South Africa (1996a, section 9 (3)).
\end{abstract}

Education laws, eg the National Education Policy Act (Act 27 of 1996) and the South African Schools Act (Act 84 of 1996), likewise accentuate human rights. The former's section $4(a)(1)$ and the latter's preamble state that national educational policy will be geared towards protecting the constitutional fundamental rights of all people in terms of "unfair discrimination within or by an education department or education institution on any ground whatsoever" (Republic of South Africa 1996b) and "that all ... forms of unfair discrimination and intolerance" will be combated (Republic of South Africa, 1996c)

The Constitution found expression in the liberating endeavours of the Department of Education (2003a:3) which steered clear of identifying "with [any] one particular religion or religious grouping" or ascribing painstakingly to the characteristics of "[a] modern secular state, which is neither religious nor anti-religious". Instead it adopted "a position of impartiality towards all religions and ... worldviews" and has been supporting the use of a co-operative model which would encourage "an ongoing dialogue between religious groups and the state in areas of common interest and concern" (Department of Education, 2003a:3). The Department of Education accentuates the fact that

religious individuals and groups ... [are] assured of their freedom from any state interference with regard to freedom of conscience, religion, thought, belief, and opinion (Department of Education (2003a:3-4).

In its attempts to promote tolerance among various religious groups, the concept of religion education as opposed to religious education was approved by Parliament on 4 August 2003 (Department of Education, 2003a). Religious 
education had covered an array of programmes in South Africa (Ferguson 1999:10). According to Roussouw (in Jarvis 2008) religious education had been taught by means of a subject that underwent several name changes. Names included Scripture, Divinity, Religious Knowledge, Bible History, Religious Instruction, Religious Education and Bible Education. Prior to the removal of religious education from public schools, the subject Biblical Studies could be taken up to grade 12 level in Black (African), Coloured and White schools. Religious education did not find expression in Indian (Hindu and Muslim) schools. Instead, the subject Right Living, which focused on universal ethical principles, was taught. (Summers \& Waddington in Jarvis 2008).

Whilst religious education includes confessional content of a particular faith, religion education is aimed at a respect of all faiths and is non-confessional in nature. Religion education is described as "teaching and learning about religion and religions" (Department of Education 2002b:26, 2003a:3; 2003b:20). Religion education is included in in the school curriculum so that learners of all grades can develop "an understanding of diverse cultures and religions" (Department of Education, 2003b:20). Biblical Studies, an elective subject, was phased out of the public school curriculum since it was considered to be religious in nature (Department of Education 2008:7). In 2008 the Department of Education (2008) reported that the subject Religion Studies had been introduced as an elective subject for grades 10-12 learners. The teaching of this subject would be based on the principle that religions would be studied without favouring or promoting any (Department of Education 2008). Religion Studies nevertheless makes allowance for grade 12 learners to undertake an in-depth study of a specific issue within the context of a specific religion (Department of Basic Education, 2011).

Currently religion education features in the subject Life Skills prescribed for the Foundation Phase (Grades R to 3) ${ }^{1}$ and Intermediary Phase (Grades 4-6)2; the subject Life Orientation prescribed for the Senior Phase (Grades 7-9) ${ }^{3}$ and the Further Education and Training Phase (Grades 10-12) ; $^{\text {; as well as the elective subject Religion Studies }}{ }^{5}$ which is relevant for the Further Training and Education Phase.

Although the decision to replace religious education with religion education was heavily debated (Chisholm 2007), its discussion in terms of historical-educational data remains restricted. Brief mention in this regard is made in papers by Chidester (2006a; 2006b), Chisholm (2003), Prinsloo (2009) and Smit and Chetty (2009). This paper aims at providing historical-educational substance relating to the South African government's decision to remove religious education from public schools. The research question which underpins this study is formulated as follows: Is the decision to remove religious education from South African public schools supported by relevant information pertaining to South Africa's educational past?

The historical-educational method was implemented to arrive at an answer to the research question. In essence, the historical-educational method entails that a historical investigation, bearing relevance to a selected topic, is undertaken and that a critical evaluation and interpretation of these are executed in order to arrive at a coherent presentation of data (Venter \& Van Heerden 1989).

\section{Historical-Educational Review}

In order to answer the research question, historical-educational information pertaining to three aspects is included in this section: formal education during South Africa's very early colonial days, formal education during the nineteenth century at the Cape, and the philosophy of Christian National Education. It should be borne in mind that a very detailed discussion of historical-educational information relating to the answering of the research question, even in terms of one of the three aspects discussed in this paper, is not possible within the scope of a single article.

\subsection{Early formal education: the association of the dominant Dutch reformed religion with segregated education}

Formal education as offered by the Dutch settlers at the Cape during the second half of the seventeenth century was characterised by the inculcation of the protestant Calvinist faith. It was based on Netherland's Education Regulation of 1650 which stated that children should be brought up in the fear of the Lord according to the reformed Christian faith. This

\footnotetext{
${ }_{1}$ Discussions of religious days that are relevant to the community have to take place as they are celebrated in the community (Department of Basic Education 2011c).

${ }^{2}$ Religion education in this phase relates to "knowledge of major religions in South Africa .... "[f]estivals and customs of a variety of religions in South Africa [and the] dignity of the person in [relation to] a variety religions in South Africa" (Department of Basic Education 2011d:11).

${ }^{3}$ Religion education relates to the "[r]ole of oral traditions and scriptures of major religions" , "[the] [c]ontributions of various organisations from various religions to social development" and the "[c]ontributions of various religions in promoting peace" (Department of Basic Education 2011b:10).

${ }^{4}$ Religion Studies includes "ethical traditions and/or religious laws and indigenous belief systems of major religions", the input of various religions in establishing and maintaining a peaceful society, and religions' relation to the "construction of recreation and physical activity across cultures and genders" (Department of Basic Education 2011a:10).

${ }^{5} \mathrm{~A}$ great variety of aspects related to religion are covered in four topics. The four topics are: the Variety of religions, the Common features of a religion as a generic and unique phenomenon, Topical issues in society and Research into and across religions (Department of Basic Education 2011e).
} 
regulation, in turn, had its foundation in decisions made at the Synod of Dordrecht (1618-1619) (Schoeman 1989). The extent to which the Dutch reformed faith influenced the Dutch society at the Cape was great, especially since the Netherlands had recently experienced victory with the conclusion of the eighty year religious war (1568-1648) against Spain (Pistorius 1982). According to Elphick (1997:2) "the public expressions of Christianity were, with minor exceptions, monopolized by the Dutch Reformed Church, closely overseen by the Dutch East India Company".

Eleven years after the arrival of the Dutch at the Cape, once it had become clear that the Dutch would settle at the Cape permanently, the first school aimed at the formal education of Dutch children was opened. Apart from twelve Dutch children, four slave children and one Khoi child attended the school. Adherence to the protestant Calvinistic religion, and not belonging to a particular ethnic group, constituted the single, initial factor of segregation at this school. Only children who had been baptised were admitted to this school which aimed at preparing learners for the confession of faith in order to obtain church membership (Schoeman 1989; Booyse 1992; Van Zyl 1997). According to Malherbe (1925) colour prejudice in education did not exist at the Cape during the early days of its colonisation. ${ }^{6}$

It is possible that the relation between ethnically based segregated schooling and the reformed Calvinist religion at the Cape can be traced back to 1676. During that year the Ecclesiastic Court (the "Kerkeraad"), "the immediate educational authority" representing the Dutch reformed faith (Malherbe 1925:33), requested the Political Council to erect a separate school for slaves. This appeal would still have a religious rationale, although ethnicity now seems to have joined religion as a basis for segregation. ${ }^{7}$ The request for the slave school was granted although it was decided that the best performing children of non-European heritage could still be sent to the school for white children (Coetzee 1958). Only in 1685 did the Dutch Commissioner, Van Rheede, saw to the establishment of a separate school for slave children so that "these poor people who were ignorant of God" could be educated (Coetzee [author's translation] 1975:5). This utterance seems to have harboured an early link between separation in terms of ethnicity and a particular interpretation of reformed Christianity since Van Rheede dictated twice that no white children were to be accommodated at that school in his regulations for the slave school. Van Rheede's stipulations of segregation, however, were not always followed. 8

The Early Dutch Reformed Church's views on segregation based on race seem to have intensified over a period of one and a half century. In this regard Greyling (1935:60), in a publication of the Federasie van Calvinistiese Studenteverenigings (Federation of Calvinist Students' Associations), states that the following Calvinist view was held by the end of eighteenth century:

no equalisation; the ordinances of God have to be acknowledged and one should not try to equalise that which God did not equalise. 9

Although Coetzee (1975) is of opinion that a system of segregated schools based on ethnicity was introduced by the Dutch at the Cape during the periods 1652-1806, absolute racial segregation at schools only became a reality at the Cape in in 1905 when it was promulgated by the School Board Act in the Cape Colony (Behr 1988; Booyse 1992).

\subsection{Nineteenth century education displaying religious-confessional based educational conflict}

This section, which focuses on particular instances during nineteenth century education in South Africa, shows that differences in religious conviction have the potential to ignite undesirable outcomes.

J.A.U. de Mist, the Commissioner General of the Batavian Republic at the Cape (1803-1806), influenced by the philosophy of liberalism that fueled the French Revolution, transferred the responsibility of controlling schools from the church to the state (Coetzee, 1958; Schoeman, 1989). He held a neutral, non-dogmatic Christian stance towards the teaching of religion. Although he objected to the teaching of the dogma of the Calvinistic faith at schools, he nevertheless decreed that religious education at schools should reflect, as far as possible, the Christian principles which represent the

\footnotetext{
${ }_{6}^{6}$ Prior to the establishment of the school under discussion, adult slaves were taught at an unsuccessful slave school which came into existence in 1658 in order to equip the slaves with a rudimentary knowledge of the Dutch language and Christianity. Its existence, however, was seemingly short lived despite attempts by Pieter van der Stael, the teacher, to reward slaves' efforts with a tot of rum and a few inches of tobacco as ordered by the Council of Policy (Malherbe 1925; Booyse (1992).

${ }^{7}$ According to Kinghorn (1990) class consciousness would automatically have been awakened at colonised areas during the seventeenth to the nineteenth centuries. He mentions that class consciousness was based on differences "along the lines of civilisation and education" and that it was not institutionalised.

8 In 1779, when eight public schools were functioning in Cape Town, 82 of a total of 696 learners were of coloured extraction (Booyse 1992). During 1793 to 1796, schools at Stellenbosch and Drakenstein provided education to both white and slave children as noted by the Scholarchs (religious Calvinist educational directors) who visited these (Coetzee, 1975; Van Zyl 1997).

${ }^{9}$ This staunch view found much support by some Christian Nationalists as shall be seen in the discussion of Christian National Education.
} 
parents' and learners' views (Schoeman 1989). ${ }^{10}$ Dutch parents were, however, extremely dissatisfied with De Mist's neglect of in-depth confessional teaching of the confessional reformed Calvinistic faith (Coetzee 1958; Schoeman 1989). The discontent of the Dutch in this regard is described as follows by Theal (in Malherbe 1925:54):

Better no education at all from books than instruction not based on religion was the cry from one end of the colony to the other.

The Dutch's conviction of the rightful place of Calvinist doctrine at school probably contributed towards the English taking a sympathetic stance towards doctrinal Calvinistic religious education at schools after they occupied the Cape in 1806. In this regard the governor, Sir John Craddock (1811-1814), decreed the implementation of the School Commission's recommendations concerning education in the country districts. The commission had recommended, inter alia, that sexton schools (the so-called "kosterskole"), which had to pay specific attention to religious education according to the Catechism and other sources determined by the minister, be established. Their main aim was to teach the Dutch learners the English language and to prepare them for church membership (Sturgis 1982; Schoeman 1989).

Confessional-religious based conflict concerning formal education occurred again during the governorship of Lord Charles Somerset (1814-1826). Although the establishment of his free schools were initially favourably accepted by the Dutch, they lost their popularity, not only because of their policy of Anglicisation, but also as a result of their neglect of confessional Calvinist religion and traditions. At these schools the Calvinist religion could only be taught for an hour on Saturdays to children of parents who were in favour of it. To address this religious neglect, private Dutch schools were established. This resulted in the free Somerset schools suffering irreparable harm (Coetzee 1958; Schoeman, 1989; Van Zyl 1997).

Further conflict based on differing views concerning the place of confessional religion at schools ccurred after the establishment of government schools by the Superintendent-General of Education, James Rose-Innes (1839-1859). These schools, which first and foremost had to mould anglicised citizens, were to provide non-doctrinal teaching of religion at schools. In order to quell dissatisfaction with this policy among Afrikaner parents, a modicum of teaching of doctrinal religion was allowed in 1841. This, however, seems to have been a temporary arrangement. By 1860, many private schools had already been established by Afrikaners as a countermeasure for English-orientated, non-doctrinal schooling. The years 1860-1890 saw an increased tenacity amongst Afrikaners in erecting more and more private schools. (Schoeman 1989). Yet the British, in general, retained their recurrent strive for non-dogmatic schools which found embodiment in the Education Act of 1865 which made provision for non-doctrinal teaching of religion after school hours if parents did not object to it. In addition to the accent on non-dogmatic schooling to alienate the Afrikaners from their culture which was enmeshed in the Calvinist reformed faith, the English propagated missionary schools, which would include the dissemination of doctrinal religion, to anglicise Africans for future subservience. In this regard Msila (2007:148) states that "whilst the missionaries provided western education to the African for the public good, they had many private interests that they wanted to fulfil". He quotes Sir George Grey, the governor of the Cape (1841-1845) in substantiating this view:

\section{We [the British] should try to make [the Blacks] a part of ourselves, with a common faith and common interests, useful} servants, contributors to our revenue.

The above allusion to employing religion for political gain constitutes a main component in understanding the philosophy of Christian National Education, the next aspect that will be discussed with a view to answering the question whether the present South African government's decision of removing religious education from schools was valid.

\subsection{Christian National Education: a nexus of politics, religion and education}

The politics of ethnic segregation, the interpretation of Calvinist religion by the Dutch Reformed Church, and education at schools had become inseparable allies before South Africa's period of apartheid. They found cohesion in the philosophy of Christian National Education (CNE) of which the nature and influence are important in interrogating the validity of the present government's decision to remove religious education from public schools.

${ }^{10}$ De Mist's objection to the teaching of dogma can possibly be related to the fact that the Cape was not completely homogeneous as far as the faiths of the colonists were concerned. De Villiers (2012:55), referring to personal religious freedom at the Cape, mentions that Lutherans, Catholics and people of other faiths could be found amongst Cape officials and the free burgers. It is therefore not impossible that children of parents not adhering to the reformed Calvinist faith would attend schools at the Cape. 


\subsubsection{Defining Christian National Education and ascertaining its educational aims}

The foundation of CNE can be traced back to the Synod of Dordrecht and subsequent Dutch education regulations. According to Schoeman (1989), CNE had always been part and parcel of the history of the Afrikaner nation and manifested itself in the Cape when the Afrikaans speaking population established its own private schools as an antipode to secular English schools. Its description in terms of its two main components, formulated at an educational congress dealing with CNE in 1906, shows that CNE had become a philosophy geared towards furthering the values of the Afrikaner people:

The term Christian education means education according to the Holy Scriptures in accordance with the articles of faith of the three Dutch Churches. National education means that the history of the [Afrikaner] nation and the language and traditions are to be taught and kept because of God's guidance in the history of the Afrikaner (Greyling [authors translation]1941:49).

1948 saw triumph for Afrikaner Nationalism. ${ }^{11}$ In the same year the Instituut vir Christelik-Nasionale Onderwys (ICNO) ("Institute for Christian National Education" (ICNE)) published its educational policy.12

According to Hofmeyr (1982) this policy constitutes the most significant description of CNE in the twentieth century because of its clarity and scope. The ICNE, too, explained CNE according to the two key concepts embedded in CNE, namely Christian Education and National Education. Christian Education was considered as education based on divine revelation as it finds expression in the confessional creeds of the three reformed Afrikaans churches. National Education referred to education which displays the national principle of love for the own which finds realisation within the domain of Christianity. The Bible and the confessions were to constitute the most important learning spheres of influence subject at schools since they had to "determine the spirit and direction of all other school subjects ..." (ICNO 1948:8-9).

According to Hofmeyr (1982), the ICNE's policy can be regarded as the most significant formulation of CNE in the twentieth century owing to its clarity and scope. It emphasised mother-tongue instruction as the only medium of instruction, the separate identity and development of each nation as God-given, parental control of schools and separate unilingual schools. With regard to Coloured and Black education, it emphasised trusteeship, segregation, the mother tongue as the medium of instruction, a Christian-National basis of education and the exclusion of White financial liability. Black education was to give rise to "an independent, self-supporting and self-sustainable native community founded on a Christian National basis" (ICNO 1948:13-29; Hofmeyr, 1982:32). Hofmeyr (1982:34) accentuates the fact that Blacks had been barred "to a varying degree from participation in activities and occupations reserved for whites" by every South African government since and preceding the unification of South Africa in 1910. The CNE Policy made no mention of formal education for Indians. CNE found articulation in subsequent education laws as well as discriminatory practices which, for example, excluded Afrikaans speaking aspirant teachers who were not members of the three Afrikaans reformed churches from being appointed (Wilkins \& Strydom 1980).

\subsubsection{Christian National Education's support of ethnic segregation based on Kuyper's religious-educational ideas}

CNE's linkage with racially based segregated education is further substantiated by the support which Abraham Kuyper's concervative ideas found amongst some Christian Nationalists, especially those belonging to the Duitse Gereformeerde Kerk (Dutch Reformed Church) and the Reformed Churches in South Africa (the"Doppers") (Strauss 1995). Kuyper's views were at times revised and adapted and placed within the framework of Afrikaner nationalism. ${ }^{13}$

\footnotetext{
${ }^{11}$ Afrikaner Nationalism is a complex concept which cannot be interpreted simplistically. In this regard O'Meara (1979:66) states that "Afrikaner nationalism is neither a monolithic ideological response by an undifferentiated Afrikanerdom, nor a product of fascism, colonial or otherwise". Afrikaner Nationalists often clashed and even their interpretation of Afrikaner unity varied. In this regard Dubow (1979: 66) mentions that General Hertzog considered all Afrikaans and English speaking white persons who considered South Africa to be their home as Afrikaners and believed that class-differences amongst Afrikaners would dictate their political alliance. He expected working class Afrikaners to support the Labour Party. These views underwent radical change after the establishment of the "purified" National Party following the National Party's coalition with General JC Smuts' South African Party.

${ }_{12}$ CNE policy-making was deemed important for furthering the newly elected political party's aspirations among Afrikaner children. It can also be viewed as a further extension of the Christian Nationalism of the 1940s, which, according to O'Meara (1979:193), represented a break with the past in the sense that it constituted a new ideology striving for "a new class alliance developed to mediate and transform the new, urban experience of capitalism [resulting in] the formation of an entirely new class of Afrikaner commercial, industrial and financial industrialists".

${ }^{13}$ Numerous interpretations for supporting apartheid were held by Christian Nationalists. They, therefore, did not constitute a homogeneous group. Rationales for apartheid included: German "volksnationalism", which accentuated the collectivity of a nation as the provider of the best means by which an individual can express his/her individuality (the nation constituted a whole that exceeded the sum of its components); metaphysical idealism, which held that differences between groups have a spiritual (metaphysical) basis unrelated to race, geographical disposition and physiognomy; deeply rooted psychological and physical variances between ethnic groups; the unavoidable necessity of racial segregation as a result of practical and historical reasons; theologized politics, which, inter alia, included the view that God willed nations to maintain their particular identity as evidenced by God's intervention at Babel where he caused people to speak in mutually incomprehensible tongues to prevent them from establishing one nation; the necessity of maintaining biological differences so as not to weaken the biological traits of a nation; and cultural incompatibility (Dubow 1991).
} 
Kuyper believed that God ordained the sovereignty of three spheres, namely the spheres of the state, society and church. Their authority, however, was subservient to God's ultimate authority. Kuyper's belief in the "sovereignty of an own sphere" was extrapolated by some Afrikaners to imply that each ethnic group constituted a sovereignty with its unique rhythm and law, finding expression in a unique language, history, biological composition and locality (Loubser 1996). This view, amongst others, would reverberate and cause debate amongst Afrikaner Nationalists who felt the need to redefine themselves after the coalition of General JBM Hertzog's National Party with General JC Smuts' South African Party which subsequently led to the establishment of The United Party in 1933. The "gesuiwerde" Nasionale Party (the "purified" National Party) which was formed by Dr DF Malan in reaction to General Hertzog's association with a so-called English speaking party (the South African Party) would entertain views accentuating unity in their strive to maintain Afrikaner identity in a time when they had to face

[t]he developing crisis in agriculture, the proletarianisation of small farmers, the acute poverty of 'poor' whites', the continuing imperialist domination of the economy [and the] economic discrimination against Afrikaans-speakers (O’Meara 1979:64).

Kuyper's views ranged from being politically conservative to relatively liberal. Kuyper's conservative views, which found support amongst some Afrikaners, were expressed in his paper, the Plancius-rede (the Plancius paper) (1884) ${ }^{14}$ and his writing De crisis in Zuid-Afrika (The crisis in South Africa)(1900) which he penned during the South African War (the Anglo Boer War) (1899-1902). In the Plancius-rede he considered the Boers of the Transvaal as pioneers of the Christian civilisation in southern and central Africa through which God would reach the African people (Strauss 1995). Boers, according to him, would "gradually [be] raising Natives to eventually make them their equal" (Kuyper [author's translation]1884:22). In De crisis in Zuid-Afrika he took an even more conservative position. He deemed the Blacks as being of a "lower race" with whom the Boers have nevertheless established very good relations (Kuyper 1900).

After the South African War, the view of Kuyper and that of his fellow Calvinists in the Netherlands as expressed in their motto "In isolation lies our strength", aimed at motivating pockets of Calvinism in the Netherlands to spread the Calvinist faith across the Dutch nation, was adapted by some conservative Afrikaners. According to them it implied political isolation-for-survival (Bosch 1986). In this regard Dubow (1991:11) states that Kuyper's ideal

of an all-embracing Christian-national Calvinist community in Holland provided a practical model for ordering social as well as religious aspects of society [within the South African context].

Kuyper's conservative political views as expressed in the Plancius-rede and the Crisis in Zuid-Afrika contradict Kuyper's liberal views expressed in his Stone Lectures delivered at Princeton University in 1898:

[T]he commingling of blood ... is the physical basis of all higher human development ... . [Groups] which by commingling have crossed their traits with those of other tribes ... have attained a higher perfection. It is noteworthy that the process of human development steadily proceeds with those groups whose historic characteristic is not isolation but the commingling of blood ... [sometimes] of very different tribes .... [T]he history of our race does not aim at the improvement of any single tribe, but at the development of mankind taken as a whole, and therefore needs the commingling of blood in order to attain its end. Now in fact history shows that the nations among whom Calvinism has flourished most widely exhibit in every way the same mingling of races (Kuyper 1931:35-36; also in Bosch 1986:209210).

Kuyper's view of the "intermingling of blood", as presented above, was transformed by some of the Afrikaner Christian Nationalists. In this regard Dubow (1991:12) states that Kuyper's acceptance of the necessity of "racial intermixture ... required [a]delicate interpretation by [some] Afrikaner nationalist adherents": The "Boers" were seen to have come into existence as a result of the intermingling of blood of "old elements of Caucasian stock" and French Huguenot blood. The purity of this "new race", however, had to be kept intact (Dubow 1991:11).

\subsubsection{CNE's close association with The Afrikaner Broederbond}

In this section, CNE's linkage with the Afrikaner Broederbond (AB) (the "Afrikaner Brotherhood') will be highlighted. The $A B$ was formed as an association geared towards the upliftment of the poor Afrikaner who had been suppressed by the English (Serfontein 1979). Despite its initial modest and noble beginnings, the AB became a secret society in 1921

\footnotetext{
14 This address was delivered in the Plancium building in Amsterdam. President SJP Kruger of the South African Republic was in attendance (Kuipers 2011).
} 
(Wilkins \& Strydom 1978) and had evolved into an elitist organisation which dominated the government, the three Afrikaans reformed churches, education and Afrikaner cultural societies by 1948 (Moodie 1975:104).

The CNE policy, which had been referred to in the previous section, was compiled by a group of AB members, involving university professors and National Party politicians, including two Cabinet ministers (Wilkins \& Strydom 1980). It displayed the AB's Christian National aspirations. According to Bloomberg (1990:37) "the Broederbond [was] both a product and the champion of the Christian-National [world-view] ... ". The influence of the AB on the three Afrikaans churches was obtained, inter alia, by means of its circulars which instructed Afrikaans reformed church members on the manner in which to further the apartheid ideology in church and how to approach criticism of the churches' rejection of freemasonry during Church Councils (Bloomberg 1990). The extent of the AB's influence on education is displayed by Serfontein's (1979:159) ironic statement that the AB was not directly involved with education after the 1948 Nationalist take-over since "[m]atters were left largely in the hands of the Government, or rather the Broeders in education".

The AB's close link with CNE is displayed, too, in its satisfaction that it had been able to entrench CNE in the National Education Policy Act (Act 39 of 1967). In this regard its chairman, on the occasion of the Afrikaner Broederbond's fiftieth anniversary in 1968, acknowledged the AB's close association with CNE and accentuated the AB's role in bringing the National Educational Policy Act into realization:

The Christian National education of the Afrikaner youth in and by ... mother-tongue instruction from kindergarten and primary school to university and other institutions of tertiary education, was one of the primary objectives of our Broederbond from the beginning ... . Our participation ... in the establishment of mother-tongue schools and the Afrikanerisation of our universities is the golden thread that runs through all our activities ... . It is also our Brotherhood that, with unstinting labour at Bond councils, in study committees and in consultation with education heads at provincial and National levels - who were and are Broeders - has been able to formulate the ideal of a National education policy for our nation and country. We have carried it through to the present stage and will continue to do so in the years that lie ahead. (Wikins \& Strydom 1980:250).

The philosophy of CNE was incorporated into the National Education Policy Act (Act 39 of 1967). The Act, in section 2 (1)(a), stipulated that education had to display a Christian character although parents' objections to their children receiving religious instruction and partaking in religious ceremonies would be respected. In section 2 (1)(b) it stated that education had to display a national character (Statutes of the Republic of South Africa 1967). ${ }^{15}$

Other acts concerning education could also be associated with CNE. The most well-known is the Bantu Education Act (Act 47 of 1953). Its section 2(a) centralised the control and administration of Black education by transferring them from provincial administration to the Union government (Statutes of the Union of South Africa 1953). Likewise, missionary education which had been responsible for more than 90\% of Blacks' schooling (Giliomee 2003), had to hand over its control to the Nationalist government ${ }^{16}$ which centralised Black education into being controlled by its Department of Native Affair's division known as Bantu Education. Education for people of colour and Indians remained under provincial control for a while. ${ }^{17}$

CNE principals found concretisation in the AB's actions. One such example pertains to the establishment of an $A B$ committee in 1959 which was tasked to deal with educational matters. This committee demanded that Afrikaans pupils' education be in accordance with the doctrines of the three reformed Afrikaans churches and the culture and history of the Afrikaner nation. By instituting a key post, namely that of Head of Department - Educational Guidance, in every Transvaal Education Department school in 1977, the AB saw to it that Afrikaans pupils were constantly reminded of their unique Christian Afrikaner identity. People in these posts had to take responsibility for religious education, youth preparedness, educational programmes in hostels, cadet training, enlightenment programmes as well as veld schools (Serfontein 1979). The AB esteemed its teacher corps highly "because of its exceptional potential for moulding the minds and attitudes of future white generations" (Wilkens \& Strydom 1998:10). Special attention was therefore paid to recruiting suitable teachers (Serfontein 1979). ${ }^{18}$

\footnotetext{
${ }^{15}$ During a parliamentary debate on 22 February 1967 that preceded the passage of the act under discussion, the then Minister of National Education described the concept National Education as it appears in the National Education Policy Bill as "education [that] shall build on the ideal of all citizens of South Africa in order that our identity and way of life may be preserved, and in order that the South African nation may constantly appreciate its task as part of the Western civilization" (Assembly Debates 1967 in Hofmeyr, 1982:76). Hofmeyr (1982) points out that "all citizens" implied white citizens only and that the CNE ideal of segregation between black and white races was perpetuated.

${ }^{16}$ Missionary schools would lose their governmental funding if they did not adhere to this demand. Almost all mission schools handed over control. The Roman Catholic Church nevertheless kept their schools open and raised funds locally and overseas. (Research Institute on Christianity in South Africa 1998).

17 The Coloured Persons Act (Act 47 of 1963 (Statutes of the Republic of South Africa 1963) and the Indians Education Act (Act 61 of 1965) (Statutes of the Republic of South Africa 1965) shifted the control and administration of education for Coloured people and Indians to central Government divisions in the Department of Coloured Affairs and the Department of Indian Affairs respectively.

${ }^{18}$ Figures relating to $A B$ membership for the year 1977 show that the teaching profession and the church accounted for $20.36 \%$ and $7.12 \%$ of a total of 1190 members respectively (Wilkins and Strydom 1980). The teaching profession constituted the largest single group in the professional sector (Serfontein 1979). The overall largest representation (18,81\%) were farmers. In 1968 the AB members in the teaching profession included 24 rectors at universities and teacher's training colleges, 171 professors, 176 lecturers, 468 school principals, 121 school inspectors and 647 teachers. The following figures are also useful in obtaining a clearer picture of Broederbond infiltration: AB membership for the year 1968 included 16 managers of newspaper groups, 22 newspaper editors, 59 secretaries or under-secretaries of departments, 16 judges, 13 advocates, 156 attorneys, 67 magistrates, 154 bank managers, 22 bank accountants and 22 other banking executives (Wilkins and Strydom 1980:362).
} 
The $A B$ furthered CNE ideals by controlling the cultural life of Afrikaners, The AB's "arbiter of the Afrikaans language", the Federasie van Afrikaanse Kultuurvereniginge (FAK) ("Federarion of Afrikaans Cultural Associations"), acted as a controller using its many cultural bodies which numbered almost 300 in 1937 . These included church councils, youth and students' associations, as well as affiliated charitable, scientific and educational groups (O'Meara 1979; Serfontein 1979).

Due to the CNE's interconnectedness with an entwined government, $A B$ and church ${ }^{19}$ (Kuperus, 1999:114), CNE became a civil religion associated with nepotism. At the 1943 Jubilee meeting of the AB in Bloemfontein in 1943, a future prime minister of South Africa stated:

The Afrikaner Broederbond must gain control of everything it can lay its hands on in every walk of life in South Africa. Members must help each other to gain promotion in the civil service or any other field of activity in which they work with a view to working themselves up into important administrative positions (Serfontein 1979:66-67).

The view above shows resemblance to an earlier address, delivered in 1934, by the then $A B$ chairman:

[T]he primary consideration is whether Afrikanerdom will reach its ultimate destiny of domination (baasskap) in South Africa. Brothers, our solution to South Africa's ailments is not whether one party or another shall obtain the whiphand, but that the Afrikaner Broederbond shall govern South Africa (Wilkins and Strydom 1980:326).

Despite its power, the $A B$ was not always homogeneous in terms of views held by its members. ${ }^{20}$ The $A B$ relinquished its secrecy in 1993 and is now operating as the Afrikanerbond whose aims are, inter alia, to mobilize the best talent and leadership qualities available in the Afrikaans speaking community in order to serve it. It is not politically affiliated and members are encouraged to join a party of their choice (Afrikanerbond 2013).

\section{Conclusion: Addressing the Issue Whether the Government's Decision to Remove Religious Education from public Schools was Justified in Terms of South Africa's Educational Past}

Discrimination in formal education, based on religious exclusivity, occurred at the first school that was established to provide formal education to Dutch children. Baptism in the reformed Calvinist faith was a prerequisite to receive formal education. Segregation based on religious doctrine seems to have been extended to include racial segregation as evidenced, inter alia, by the establishment of a school exclusively for slave children. Since historical facts show that discriminatory practice based on confessional religion took place in formal during the period of early colonisation at the Cape, they support the government's decision to remove religious education from public schools. The discriminatory practice of segregation during South Africa's early history of formal education constitutes a retrospective injustice in terms of South Africa's democratic constitution. As shown, it later underwent "refinement" when Christian National Education accentuated racial segregation within its particular interpretation of Calvinism which supported its political views.

Education during the nineteenth century at the Cape show that differing views on the teaching of religion held by the English and the Dutch (confessional versus non-confessional) resulted in conflict. Bearing in mind the greater diversity of religions that could be represented by learners in desegregated schools, the government acted wisely to prevent conflict of a very complex nature by removing religious education from public schools. Rather focusing on commonalities in religions by means of religion education to allow cultures to get to know one another was a much better option.

Historical facts in terms of CNE relates to the exclusion of religious education from public schools since they show that a particular politicised interpretation of a religion, influential support and biased interpretations of written works can do much in furthering racial segregation. They reveal that CNE's exclusive interpretation of the Calvinist faith, support of Kuyper's conservative views and its adaptation of others to suit its political principles, as well as the support of the members of the powerful Afrikaner Broederbond, dominated education, inter alia, by means of the National Education Policy Act (Act 39 of 1967) which the AB claimed it had furnished with CNE principles. The fact that many teachers had

\footnotetext{
${ }^{19}$ The AB's influence on the affairs of the three reformed Afrikaans churches was prominent. By 1979 the leadership of the three Afrikaans churches was in the hands of the $A B$ members who occupied all the key positions, such as the posts of editors of church magazines and moderators. Broeders had a dominating influence on church councils although they seldom exceeded 10 or $15 \%$ of the 70 to 80 council members (Serfontein 1979).

20 After the National Party split in 1982 as a result of the envisaged tricameral parliament which made provision for certain educational functions being controlled by three sectors of the population, namely Whites, Blacks and Coloured people, the $A B$, like the DC, reflected this division (Kuperus 1999). According to Giliomee (2003:581, 603), the AB "had purged itself from most of its very conservative members by the early 1980s ... [and] mirrored divisions in NP ranks". Drastic change in AB views was reflected in a 1986 AB memorandum entitled Basic Constitutional Values for the Survival of Afrikaners. It, surprisingly, considered the "exclusion of Blacks at the highest level of decision making as a threat to the survival of Whites" (Giliomee, 2003:621). The AB experienced a great decline in membership. About a third of its members left after the above-mentioned AB document reached the $A B$ branches (Giliomee 2003).
} 
been exposed to the philosophy of CNE during their formal education at school and higher educational institutions supports government's decision to dismiss religious education from schools, thereby preventing the possibility of religious education being once again shaped into a tool of oppression and supporting the Constitution.

Historical evidence supports the government's decision to exclude religious education from public schools. Considering that religion education "has a civic rather than a religious function, and promotes civic rights and responsibilities" (Chidester 2003:262; DoE 2006), thereby acting as an antidote against the segregation of people and striving for the lofty Platonic ideal of realising the universal common good for all, its inclusion in the school curriculum seems admirable. The goals of religion education resonate with those of the National Interfaith Leadership Council of South Africa (established September 2011) which support the assumption that different religions have similar morals as a common denominator working towards "mutual respect and understanding and in doing so, challenges ignorance and prejudice" (Republic of South Africa, 2011: 2833).

\section{References}

Afrikanerbond. (2013). As Afrikander bou ons saam aan die toekoms van Suid-Afrika. [Online] Available: http://www/afrikanerbond.co/za. (April, 30 2013)

Behr, A.L. (1988). Education in South Africa. Origins, issues and trends: 1652-1988. Pretoria: Academica.

Bloomberg, C. (1990). Christian-Nationalism and the rise of the Afrikaner Broederbond in South Africa. Edited by Saul Dubow. London: Macmillan.

Booyse, J.J. (1992). 'n Historiese beskrywing en evaluering van die ontstaan, ontwikkeling en grondslae van "Peoples Education". Unpublished thesis. Pretoria: Universiteit van Suid Afrika.

Bosch, D.J. (1986). The Afrikaner and South Africa. Theology Today, 43(2):204-216.

Chidester, D. (2003). Religion Education in South Africa: Teaching and learning about religion, religions, and religious diversity. British Journal of Religious Education, 25(4):261-278).

Chidester, D. (2006a). Religion education and the transformational state in South Africa. The International Journal of Social and Cultural Practice, 50(3): 61-83.

Chidester, D. (2006b). Religion education in South Africa: teaching and learning about religion, religions, and religious diversity. British Journal of Religious Education, 25(4): 261-278.

Chisholm, L. (2003). The politics of curriculum review and revision in South Africa. Paper presented at the International Conference on Education and Development. Oxford, $9-11$ September.

Chisholm, L. (2007). The making of South Africa's National Curriculum Statement. Journal of Educational Studies 37(2), 193-208.

Coetzee, J. Chr. (1975). Onderwys in Suid-Afrika 1652 - 1960. Pretoria: JL van Schaik.

Department of Basic Edcucation. (2011a). National Curriculum Statement (NCS). Curriculum and assessment policy statement. Life Orientation. Further Education and Training Phase. Grades 10-12. [Online] Available: http://www.education.gov.za (May, 25 2014)

Department of Basic Edcucation. (2011b). National Curriculum Statement (NCS). Curriculum and assessment policy statement. Life Orientation. Senior Phase. Grades 7-9. [Online] Available: http://www.education.gov.za (May, 25 2014)

Department of Basic Education. (2011c). National Curriculum Statement (NCS). Curriculum and assessment policy statement. Life Skills. Foundation Phase. Grades R-3. [Online] Available: http://www.education.gov.za (May, 25 2014)

Department of Basic Education. (2011d). National Curriculum Statement (NCS). Curriculum and assessment policy statement. Life Skills. Intermediary Phase. Grades 4-6. [Online] Available: http://www.education.gov.za (May, 25 2014)

Department of Basic Edcucation. (2011e). National Curriculum Statement (NCS). Curriculum and assessment policy statement. Religion Studies. Further Education and Training Phase. Grades 10-12. [Online] Available: http://www.education.gov.za (May, 25 2014)

Department of Education. (2002a). Revised National Curriculum Statement. Grades R-9. Life Orientation. Government Gazette 443 Pretoria: Government Printer.

Department of Education. 2002b. Revised National Curriculum Statement Grades R-3. Overview. Government Gazette 443, 2002. Pretoria: Government Printer.

Department of Education. 2003a. National policy on religion and education. Pretoria: Government Printer.

Department of Education. (2003b). Revised national curriculum statement grades R-9 (Schools). Teacher's guide for the development of learning programmes. Life orientation. Pretoria: Government Printer.

Department of Edcuation. (2008). National Curriculum Statement. Grades 10-12. Learning programme guidelines. Religion Studies. Available: www.education.gov.za (January, 15 2013)

De Villiers, J. (2012). Die Nederlandse era aan die Kaap, 1652-1806. In: F Pretorius, (ed.). Geskiedenis van Suid-Afrika. Van voortye tot vandag. Kaapstad: Tafelberg.

Dubow, S. (1991). Afrikaner nationalism, apartheid, and the conceptualisation of "race". University of the Witwatersrand: African Studies Institute.

Elphick, R. 1997. Introduction: Christianity in South African history. In: R. Elphick, R \& R. Davenport (eds.). Christianity in South Africa. A political, social, and cultural history. Berkeley: University of California Press.

Ferguson, R. (1999). Strategies for teaching religion in Colleges of Education. Unpublished dissertation. Stellenbosch: University of 
Stellenbosch.

Giliomee, H. (2003). The Afrikaners. Biography of a people. Cape Town: Tafelberg.

Giliomee, H. (2012). "n "Gesuiwerde" nasionalisme, 1924 - 1948. In: F Pretorius (ed.). Geskiedenis van Suid-Afrika. Van voortye tot vandag. Kaapstad: Tafelberg.

Greyling, E. 1941. Christelike en Nasional Onderwys. Deel II. Bloemfontein: Nasionale Pers.

Hofmeyr, J.M. (1982). An examination of the influence of Christian National Education on the principles underlying white and black education in South Africa: 1948-1982. Unpublished MEd dissertation. Johannesburg: University of the Witwatersrand.

ICNO (Instituut vir Christelik-Naionale Onderwys). (1948). Christelik-Nasionale Onderwysbeleid. Johannesburg: Instituut vir ChristelikNasionale Onderwys.

Jarvis, J. (2008). The voice of the teacher in the context of religious freedom: a Kwazulu-Natal case study. Unpublished MEd dissertation. Stellenbosch: University of Stellenbosch.

Kinghorn, J. (1990). The theology of separate equality: a critical outline of the DRC's position on apartheid. In: M Prozesky (ed.). Christianity in South Africa. Bergvlei: Southern Book Publishers.

Kuipers, T. (2011). Abraham Kuyper. An annotated bibliography. 1857-2010. Series in Church History, Vol 55. Leiden: Brill.

Kuperus, T. (1999). State, civil society and apartheid in South Africa. An examination of Dutch Reformed church-state relations. London: Macmillan Press Ltd.

Kuyper, A. (1884. Plancius-rede. Amsterdam: JH Kruyt.

Kuyper, A. (1900). De crisis in Zuid-Afrika. Translated by CK Elout from "Revue des deux mondes". Amsterdam: Boekhandel (previously Höveker \& Wormser).

Kuyper, A. (1931). Lectures on Calvinism. Michigan: Grand Rapids.

Loubser, J.A. (1996). Apartheid theology: a contextual theology gone wrong. Journal of Church and State, 38(1):321-337.

Malherbe, E.G. (1925). Education in South Africa. Vol I: 1652-1922. Cape Town: Juta \& Co Ltd.

Moodie, T.D. (1975). The rise of the Afrikanerdom. Power, apartheid, and the Afrikaner civil religion. Berkeley: University of California Press.

Msila, V. (2007). From apartheid education to the Revised National Curriculum Statement: Pedagogy for identity formation and nation building in South Africa. Nordic Journal of African Studies, 16(2):146-160.

O'Meara, D. (1979). Class, capital and ideology in the development of Afrikaner nationalism, 1934-1948. Unpublished thesis. Sussex: University of Sussex.

Pistorius, P. (1982). Gister en vandag in die opvoeding. Potchefstroom: Pro Rege.

Prinsloo, P. (2009). The South African Policy on Religion and Education (2003): a contradiction in a secular state and age? Alteration, 3 : 31-54.

Republic of South Africa (1996a). Constitution of the Republic of South Africa (Act 108 of 1966). Government Gazette Vol 378, no 17679. Preoria: Government Printer.

Republic of South Africa (1996b). National Education Policy Act (Act 27 of 1996). Government Gazette Vol 370, no 17118. Pretoria: Government Printer.

Republic of South Africa (1996c). South African Schools Act (Act 84 of 1996). Government Gazette Vol 377, no 17579. Pretoria: Government Printer.

Republic of South Africa. (2011). Minutes of proceedings of National Assembly. No 32-2011, Tuesday, 13 September. Available: http:www.parliament.gov.za/live/commonrepository/Processed/20110914/363723 (April, 20 2013)

Research Institute on Christianity in South Africa. (1998). Report prepared for The Truth and Reconciliation Commission. Chapter 2: Faith communities. [Online] Available: http://web.uct.ac.za/depts/ricsa/commiss/trc_ch2.htm (March, 27 2013)

Schoeman, S. (1989). Die invloed van die Calvinistiese lewensbeskouing op die onderwys in Suid-Afrika: 'n histories-opvoedkundige ondersoek en evaluering. Unpublished thesis Pretoria: University of South Africa.

Serfontein, J.H. (1979). Brotherhood of power. An exposé of the secret Afrikaner Broederbond. London: Routledge.

Smit, A. \& Chetty, D. (2009). Advancing religious studies in Southern Africa. Alternation 3: 331-353.

Statutes of the Republic of South Africa 1967. National Education Policy Act. (Act No 39 of 1967). Pretoria: Government Printer.

Statutes of the Union of South Africa 1953. Bantu Education Act (Act No 47 of 1953). Parow, Cape Town: Government Printer.

Strauss, P.J. 1995. Abraham Kuyper, apartheid and reformed churches in South Africa in their support of apartheid. Theological Forum, 23(1): 4-27.

Sturgis, J. (1982). Anglicisation at the Cape of Good Hope in the early nineteenth century. The Journal of Imperial and Commonwealth History, 11(1):5-32.

Sturm, R., Groenedijk, L., Kruithof, B., \& Rens, J. (1998). Educational pluralism - a historical study of so-called "pillarization" in the Netherland, including a comparison with some developments in South African education. Comparative Education, 34 (3):281297.

Van Zyl, A. (1997). A historical overview of South African education, In: E. Lemmer \& D.C. Badenhorst (eds.). Introduction to education for South African teachers: an orientation to teaching and learning. Kenwyn: Juta \& Co Ltd.

Venter, I.S.J. \& Van Heerden, S. M. (1989). The grounding of History of Education. Pretoria: Euro Publications.

Wilkins, I. \& Strydom, H. 1980. The Super-Afrikaners. Johannesburg: Jonathan Ball Publishers. 